\title{
Overwintering Potential of Onion in Kentucky
}

\author{
Timothy Coolong ${ }^{1,3}$ and Mark A. Williams ${ }^{2}$
}

AdDitional InDEx wORDs. Allium cepa, bolting, pungency, rowcover, straw mulch, vegetable production

SUMMARY. Eight cultivars of onion (Allium cepa) representing, long, intermediate, and short-day types were evaluated for their ability to be overwintered in Kentucky. Onion seedlings were transplanted in Nov. 2007 and Oct. 2008. Plants were covered with spunbonded rowcovers or wheat (Triticum sp.) straw mulch in December and mature bulbs were harvested in June and July. Bulbing was initiated in 'Yellow Granex' (short-day) during transplant production, thus it was not planted in the field in either year of the experiment. The use of rowcovers compared with straw mulch increased survival rates in all cultivars. The intermediate-

daylength cultivars, Candy, Superstar, and Expression, had greater percentages of bolting when grown under rowcovers compared with straw mulch. This resulted low marketable yields despite high survival rates. Rowcover/mulch treatment and cultivar interacted $(P \leq 0.05)$ to affect yields. The long-day cultivars, Olympic, Ailsa Craig, and Walla Walla had the highest yields when grown under rowcovers.

'Olympic', the highest yielding cultivar, produced a large percentage of jumbo-sized bulbs. The short-day cultivar, WI-131, had low survival rates and yields under rowcovers and straw mulch. Pungencies were lowest in 'WI-131' and 'Olympic'. In general, long-day onion cultivars had high rates of survival, low rates of bolting, and higher yields compared with intermediate-day types. This suggests that they would be preferred for overwinter production in Kentucky.

$\mathrm{O}$ nions are grown throughout the United States using multiple production systems in a range of climates. Onions are typically divided into short-day, intermediateday, and long-day types; with bulbing occurring in response to daylengths greater than or equal to $11-12 \mathrm{~h}, 13-$ $14 \mathrm{~h}$, and greater than $14 \mathrm{~h}$, respectively (Rubatzky and Yamaguchi, 1997). Daylength during the winter and early spring months in southern regions of the United States allows short-day types to be grown for overwinter production in areas such as the Vidalia region of Georgia (Boyhan and Torrance, 2002). Long- and intermediate-day types are used for spring and summer production in more northern latitudes of the United States.

Onion production in states such as Kentucky and Tennessee has more in common with northern parts of the United States than with southern regions. Although Kentucky has a

We acknowledge the Crop Diversification and Biofuel Research and Education Center at the University of Kentucky, established through a USDA Special Grant, for funding this project.

${ }^{1}$ Department of Horticulture, 2360 Rainwater Road, University of Georgia, Tifton, GA 31793

${ }^{2}$ Department of Horticulture, N-318 Agricultural Sciences North, University of Kentucky, Lexington, KY 40546

${ }^{3}$ Corresponding author. E-mail: tcoolong@uga.edu. relatively mild winter climate, short periods of killing temperatures for onion occur. Many onion cultivars grown in the United States are killed when exposed to temperatures below $-10{ }^{\circ} \mathrm{C}$ (Corgan and Kedar, 1990). Therefore, onions are typically transplanted in April and harvested in July and August in Kentucky (Coolong et al., 2011). However, on-farm observations by the authors suggest that onions may be overwintered in Kentucky. Intermediate- and longday types are often grown as they are appropriate for the daylengths experienced in this region during late spring and early summer (Coolong et al., 2011). Short-day onions are not currently recommended for spring plantings in Kentucky, because of premature bulb initiation. However, growing plants during winter months when daylengths are shorter may allow for successful production.

Although onion bulbing is primarily a photoperiodic response, it can also be influenced by environmental factors such as temperature, light intensity, nitrogen $(\mathrm{N})$ fertility, and irrigation (Brewster, 1990). Once exposed to a minimum photoperiod, bulbing increases with older or larger plants (Sobeih and Wright, 1986). Therefore, fall-planted onions mature earlier than those which are spring planted, allowing harvests in cooler temperatures. Bacterial pathogens of onion such as sour skin (Burkholderia cepacia) and center rot (Pantoea ananatis), which thrive in hot weather, may also be avoided (Schwartz and Mohan, 1995). In addition, earlier harvests may provide marketing opportunities for growers. Furthermore, onions have been shown to have a milder flavor potential when grown under cooler temperatures (Coolong and Randle, 2003a).

Despite positive aspects of overwinter onion production for growers in Kentucky, limitations exist. Onion cultivars can vary significantly in their ability to withstand freezing temperatures (Corgan and Kedar, 1990; Gill and Waister, 1983). Short-, intermediate-, and long-day onion cultivars have been developed for production in distinct environments (Hanelt, 1990) and may vary in their survival ability and yield potential when overwintered in Kentucky.

Observations suggest the use of plastic mulches and rowcovers may enhance the winter survival of fieldgrown onions in Kentucky. Although the use of black-polyethylene mulch has been reported to increase yield in overwintered onions in northern Florida (Hochmuth et al., 1990),

\begin{tabular}{llll}
\hline $\begin{array}{l}\text { Units } \\
\begin{array}{l}\text { To convert U.S. to SI, } \\
\text { multiply by }\end{array}\end{array}$ & U.S. unit & SI unit & $\begin{array}{l}\text { To convert SI to U.S., } \\
\text { multiply by }\end{array}$ \\
\hline 0.4047 & $\mathrm{acre}(\mathrm{s})$ & $\mathrm{ha}$ & 2.4711 \\
1 & $\mathrm{cbar}$ & $\mathrm{kPa}$ & 1 \\
0.0731 & $\mathrm{fl} \mathrm{oz} / \mathrm{acre}$ & $\mathrm{L} \cdot \mathrm{ha}^{-1}$ & 13.6840 \\
0.3048 & $\mathrm{ft}$ & $\mathrm{m}$ & 3.2808 \\
3.7854 & $\mathrm{gal}$ & $\mathrm{L}$ & 0.2642 \\
2.54 & inch(es) & $\mathrm{cm}$ & 0.3937 \\
0.4536 & $\mathrm{lb}$ & $\mathrm{kg}$ & 2.2046 \\
1.1209 & $\mathrm{lb} / \mathrm{acre}$ & $\mathrm{kg} \cdot \mathrm{ha}^{-1}$ & 0.8922 \\
0.0254 & $\mathrm{mil}$ & $\mathrm{mm}$ & 39.3701 \\
33.9057 & $\mathrm{oz} / \mathrm{yard}{ }^{2}$ & $\mathrm{~g} \cdot \mathrm{m}^{-2}$ & 0.0295 \\
1 & $\mathrm{ppm}$ & $\mathrm{mg} \cdot \mathrm{L}^{-1}$ & 1 \\
$\left({ }^{\circ} \mathrm{F}-32\right) \div 1.8$ & ${ }^{\circ} \mathrm{F}$ & ${ }^{\circ} \mathrm{C}$ & $\left({ }^{\circ} \mathrm{C} \times 1.8\right)+32$ \\
& & &
\end{tabular}


elevated temperatures, which are detrimental to growth, were reported for onions grown using black-plastic mulches in Georgia (Diaz-Perez et al., 2004). Walters (2008) reported improved overwinter production of garlic (Allium sativum) in southern Illinois when grown on black-plastic mulch compared with plants grown with straw mulch on bare soil. Mansour and Hemphill (1987) reported a yield improvement for spring-planted green onions grown in Oregon under a spunbonded polyester rowcover compared with those grown on bare ground. Onions were successfully overwintered in New Hampshire using a combination of 6-mil plastic and rowcover (1.25 $\left.\mathrm{oz} / \mathrm{yard}^{2}\right)$ in a low-tunnel structure (Sideman and Bryant, 2013). Increase in air temperatures of more than $20{ }^{\circ} \mathrm{F}$ were reported for the low-tunnel structure in that trial.

The objective of this research was to optimize overwinter onion production for growers in Kentucky and similar growing regions. Plastic low tunnels, although effective in New Hampshire, were not used in this study as there were concerns about excessive temperatures occurring under the plastic during sunny days in the winter. Several onion cultivars, representing short-, intermediate-, and long-day types were grown.

\section{Materials and methods}

This study was conducted from 2007 to 2009 at the University of Kentucky Horticulture Research Farm in Lexington, Kentucky (lat. $38^{\circ} 3^{\prime} \mathrm{N}$, long. $\left.84^{\circ} 30^{\prime} \mathrm{W}\right)$. The soil was a Maury silt loam series $(0 \%$ to $2 \%$ slope), which is a fine, mixed, mesic Typic Alfisol. Weather data were obtained from a nearby weather station (University of Kentucky, 2014). Eight cultivars of onion were grown representing short-, intermediate-, and long-day types. 'Yellow Granex' (Seedway, Elizabethtown, PA) and 'WI-131' (Wannamaker Seeds, Saluda, NC) are short-day types. 'Candy', 'Expression' (Seedway), and 'Superstar' (Johnny's Selected Seeds, Winslow, $\mathrm{ME}$ ) are intermediate-day types; and 'Walla Walla', 'Ailsa Craig' and 'Olympic' (Johnny's Selected Seeds) are long-day types. 'Superstar' is a white cultivar, whereas all others are yellow skinned.
Seed were planted into 200-cell greenhouse trays filled with soilless media (Pro-Mix BX; Premier Tech, Riviere-du-Loup, QC, Canada) on 22 Aug. 2007 and 7 Aug. 2008. Seedlings were greenhouse grown with temperature set points of $30 /$ $25{ }^{\circ} \mathrm{C}$ (day/night). Plants were watered daily as needed and fertilized weekly with a $150 \mathrm{mg} \cdot \mathrm{L}^{-1} \mathrm{~N}$ solution (20N-4.4P-16.6K; Scotts, Marysville, $\mathrm{OH})$. Daylength during transplant production ranged from $\approx 10.5$ to $13 \mathrm{~h}$ in Lexington, KY. At these daylengths, bulbing was induced in transplants of 'Yellow Granex' in both years. Therefore, 'Yellow Granex' was not planted as it was not suitable for overwinter production. On 9 Nov. 2007 and 23 Oct. 2008, seedlings were planted using a waterwheel planter. Onion plants were set into 4to 5 -inch-tall raised beds covered with 1-mil embossed black-plastic mulch with a single line of drip irrigation tubing (12-inch emitter spacing, $0.45 \mathrm{gal} / \mathrm{min}$ per $100 \mathrm{ft}$, Aqua-Traxx; Toro, El Cajon, CA) placed $\approx 1$ inch below the soil surface in the center of each bed. Onions were grown using black-polyethylene mulch for weed protection and to increase spring soil temperatures (Lamont 2005). Wheat-straw mulch or spunbonded rowcovers were used for plant protection. Wheat-straw mulches are commonly used throughout Kentucky for low-cost overwinter protection of crops such as strawberry [Fragaria $\times$ ananassa (J. Strang, personal communication)].

Raised beds were $\approx \mathbf{3 0}$ inches across and spaced on 6 -ft centers. Each bed contained five rows of onions spaced 6 inches within and between rows. This resulted in a population of 72,000 plants/acre. Experimental units (plots) contained 200 plants each and were separated from adjacent plots within the same row by $6 \mathrm{ft}$. A spunbonded rowcover (1.5 oz/yard ${ }^{2}$, AG-50 ${ }^{\circledR}$; Agribon, Mooresville, NC) or wheat-straw mulch (3-inch depth) was applied on 13 Dec. 2007 and 3 Dec. 2008. The rowcover chosen for this experiment was the heaviest weight available in the region and thus offered the most protection potential for the onions. The straw mulch was applied at a 3inch depth, providing protection, but shallow enough to allow transplants to receive light. Protective treatments were initiated when nighttime temperatures below freezing were routinely experienced. Wire hoops were placed in the rowcover plots for support. Hoops were placed $\approx 5 \mathrm{ft}$ apart in a row. The experiment was set up as a seven by two factorial in a randomized complete block design with three replications.

In 2007, $25 \mathrm{lb} /$ acre N (34N0P-0K; Southern States Cooperative, Richmond, VA) was applied before laying the plastic mulch. Supplemental potassium and phosphorous were not necessary in 2007 according to soil tests. In 2008, $25 \mathrm{lb} /$ acre $\mathrm{N}$ (19N-8.3P-15.8K; Southern States Cooperative) was applied under the plastic mulch. In Spring 2008 and 2009 , plants received an additional $125 \mathrm{lb} /$ acre N (15.5N-0P-0K calcium nitrate; Southern States Cooperative) through drip irrigation beginning in March and continuing through May. Tensiometers (12 inch length; Irrometer Co., Riverside, CA) were placed in each row and were monitored to determine irrigation frequency. Irrigation was initiated when the tensiometers reached about $-35 \mathrm{kPa}$ and was ended at about $-10 \mathrm{kPa}$.

Rowcovers and wheat-straw mulch were removed on 10 Mar. 2008 and 18 Mar. 2009 because of daily temperatures routinely exceeding $50{ }^{\circ} \mathrm{F}$ and a resumption of plant growth. No fungicides were applied in either year. The insecticide, permethrin, $4.61 \mathrm{fl} \mathrm{oz} /$ acre (Pounce $3.2 \mathrm{EC}$; FMC Corp., Philadelphia, PA) was applied in early and mid-May during both years for control of thrips (Thrips sp.). Harvests were initiated when at least $50 \%$ of plants of a cultivar demonstrated pseudo-stem softening (tops down). Harvests began on 2 June 2008 and 12 June 2009, and were ended on 8 July in 2008 and 2009. Bulbs were cured for $7 \mathrm{~d}$ at 35 / $25{ }^{\circ} \mathrm{C}$ (day/night). Harvested bulbs were weighed and graded according to USDA fresh market onion grade standards for Bermuda-GranexGrano types (USDA, 1995). Dry matter content and number of bulbs with multiple centers were determined on 10-bulb samples from each cultivar and treatment combination. The presence of multiple centers was determined by cutting bulbs equatorially and counting the number of growing points that were at 
least $2 \mathrm{~cm}$ from the center of the bulb. Additional 10-bulb samples were analyzed for total soluble solids content pyruvic acid content [EPY (pungency)] using the method of Randle and Bussard (1993) at the National Onion Laboratories, Collins, GA. In 2008, bulbs of 'Expression' were not analyzed for SSC or EPY because of damage received during shipping.

Data from both years were analyzed using analysis of variance (PROC GLM) with SAS (version 9.1; SAS Institute, Cary, NC). Analysis of variance included onion cultivar, rowcover/ straw-mulch treatment, year, and their interactions as sources of variance. Cultivar and rowcover/mulch treatment were separated using Fisher's least significant difference test $(P \leq 0.05)$.

\section{Results and discussion}

Onion plant survival. There were significant cultivar by rowcover treatment interactions $(P \leq 0.05)$ affecting onion plant survival (Table 1). In 2007-08, all cultivars, when grown under rowcovers, with the exception of WI-131, had survival rates that were not different; ranging from $85 \%$ to $97 \%$. In $2008-09$, 'Walla Walla', 'Ailsa Craig', 'Olympic', 'Candy', and 'Superstar' grown with rowcovers had the highest survival (SSC) and enzymatically produced

rates, ranging from $68 \%$ to $89 \%$ ( $\mathrm{Ta}-$ ble 1). In both years of the study, 'Walla Walla' and 'Olympic' had the highest survival rates of cultivars grown with straw mulch, although in 2008-09 several cultivars grown with straw had survival rates that were not significantly different from 'Olympic'. 'WI-131' had the lowest survival rate for cultivars grown under straw mulch, but this might be expected as it has been bred to grow in the Vidalia region of Georgia, which typically experiences mild winter temperatures (Boyhan and Kelley, 2007)

Onion plant survival was significantly lower in 2008-09 compared with 2007-08 (Table 2). Although the average high and low temperatures were similar during both years of the experiment, there were $18 \mathrm{~d}$ with minimum temperatures below $-10{ }^{\circ} \mathrm{C}$ during 2008-09 compared with $10 \mathrm{~d}$ in 2007-08 (University of Kentucky, 2014). In addition, the minimum air temperature for 2008 09 was $-19.5{ }^{\circ} \mathrm{C}$ compared with $-15.5{ }^{\circ} \mathrm{C}$ during $2007-08$. Overall, 'Walla Walla' and 'Olympic', both long-day types, consistently had the highest survival rates in both production years. Long-day onions have been adapted to northern latitudes where colder temperatures are likely

Table 1. Survival and flowering (bolting) percentage for seven onion cultivars grown overwinter in 2007-08 and 2008-09 with rowcovers [R (AG 50 ${ }^{\circledR}$; Agribon, Mooresville, NC)] or wheat-straw mulch (S) in Lexington, KY.

\begin{tabular}{|c|c|c|c|c|}
\hline \multirow[b]{3}{*}{ Cultivar (treatment) ${ }^{\mathrm{z}}$} & \multicolumn{2}{|c|}{ 2007-08 } & \multicolumn{2}{|c|}{ 2008-09 } \\
\hline & Survivaly $^{y}$ & Flowering $^{\mathrm{x}}$ & Survival & Flowering \\
\hline & \multicolumn{4}{|c|}{$(\%)$} \\
\hline Walla Walla (R) & $97 a^{w}$ & $11 \mathrm{c}$ & 89 a & $4 \mathrm{~cd}$ \\
\hline Ailsa Craig (R) & $94 \mathrm{a}$ & $13 c$ & $74 \mathrm{ab}$ & $6 \mathrm{~cd}$ \\
\hline Olympic (R) & $94 \mathrm{a}$ & $1 \mathrm{c}$ & $85 \mathrm{a}$ & $0 \mathrm{~d}$ \\
\hline Expression (R) & $89 \mathrm{ab}$ & $67 \mathrm{a}$ & $50 \mathrm{c}$ & $41 \mathrm{~b}$ \\
\hline Candy $(\mathrm{R})$ & $87 \mathrm{ab}$ & $61 \mathrm{a}$ & $75 \mathrm{ab}$ & $46 \mathrm{~b}$ \\
\hline Superstar (R) & $85 \mathrm{ab}$ & $42 \mathrm{~b}$ & $68 \mathrm{~b}$ & $63 \mathrm{a}$ \\
\hline Walla Walla (S) & 79 bc & $1 \mathrm{c}$ & $38 \mathrm{~cd}$ & $2 \mathrm{~d}$ \\
\hline Olympic (S) & $76 \mathrm{bc}$ & $0 \mathrm{c}$ & 24 de & $0 \mathrm{~d}$ \\
\hline WI-131 (R) & $69 \mathrm{c}$ & $0 \mathrm{c}$ & $35 \mathrm{~cd}$ & $0 \mathrm{~d}$ \\
\hline Ailsa Craig (S) & $43 \mathrm{~d}$ & $1 \mathrm{c}$ & 19 ef & $0 \mathrm{~d}$ \\
\hline Candy $(S)$ & $34 \mathrm{~d}$ & $13 \mathrm{c}$ & 14 efg & $16 \mathrm{c}$ \\
\hline Superstar (S) & $12 \mathrm{e}$ & $2.7 \mathrm{c}$ & $11 \mathrm{efg}$ & $16 \mathrm{c}$ \\
\hline Expression $(S)$ & $7 \mathrm{e}$ & $0 \mathrm{c}$ & $7 \mathrm{fg}$ & $6 \mathrm{~cd}$ \\
\hline WI-131 (S) & $3 \mathrm{e}$ & $0 \mathrm{c}$ & $1 \mathrm{~g}$ & $0 \mathrm{~d}$ \\
\hline
\end{tabular}

z'Ailsa Craig', 'Olympic', and 'Walla Walla' (long-day); 'Candy,' 'Expression,' and 'Superstar' (intermediate-day); 'WI-131' (short-day).

yercent survival based on the number of plants surviving out of 200 planted.

xercentage of flowering were based on number of plants with flowers divided by the number of plants surviving in each plot.

"Means within a column followed by the same letter are not significantly different according to Fisher's least significant difference test at $P \leq 0.05$. to be experienced during production (Brewster, 1990).

Although there were significant interactions $(P \leq 0.05)$ between cultivar and rowcover/mulch treatment, onion plants had greater survival rates when grown using rowcovers compared with straw mulch (Table 2). Plants grown using rowcovers had an $88 \%$ and $67 \%$ rate of survival in 2007-08 and 2008-09, respectively (Table 2); whereas, plants grown using wheat-straw mulch had survival rates of $36 \%$ and $17 \%$ in $2007-08$ and 2008-09, respectively. This suggests that straw mulch offers limited protection to plants compared with spunbonded rowcovers. On-farm experiments in Kentucky suggest a 1-2 ${ }^{\circ} \mathrm{C}\left(1.8-3.6^{\circ} \mathrm{F}\right)$ increase in average air temperatures under a similar weight rowcover when used in early spring (data not shown). Ibarra and DiazPerez (2001) reported increases in average air temperatures of 4.7$11.5^{\circ} \mathrm{C}\left(8.46-19.80{ }^{\circ} \mathrm{F}\right)$ for muskmelons (Cucumis melo) grown on black-plastic mulch under rowcover $\left(0.5 \mathrm{oz} / \mathrm{yard}^{2}\right)$ for short periods after seeding in the spring. Sideman and Bryant (2013) reported increases in minimum air temperatures of more than $20^{\circ} \mathrm{F}\left(11.1^{\circ} \mathrm{C}\right)$ for low tunnels constructed of clear plastic (6-mil) and rowcover $\left(1.25 \mathrm{oz} / \mathrm{yard}^{2}\right)$ when used for the winter season in New Hampshire. Soil temperatures in the tunnels were also maintained above freezing throughout winter in that study. Although the present study used spunbonded rowcovers without plastic low tunnels, soil temperatures were likely increased, which may have reduced desiccation of plants grown under rowcovers.

ONION PLANT BOLTING. In 200708, 'Expression' and 'Candy' grown under rowcovers had the highest rates of bolting, with $67 \%$ and $61 \%$, respectively (Table 1 ). 'Superstar' had the highest rate of bolting when grown under rowcovers in 2008-09 at $63 \%$. There was a significant cultivar by rowcover/mulch treatment interaction $(P \leq 0.05)$ for bolting incidence. Three cultivars with the highest bolting rates, Expression, Candy, and Superstar, also had the greatest relative increase in survival because of the presence of rowcovers. In both study years 'Expression' experienced the greatest relative increase in survival rate when grown 
Table 2. Onion survival and flowering (bolting) comparing seven cultivars, overwintering protection treatment, and year for the winters of 2007-08 and 2008-09 in Lexington, KY.

\begin{tabular}{|c|c|c|c|c|}
\hline & \multicolumn{2}{|c|}{$2007-08$} & \multicolumn{2}{|c|}{ 2008-09 } \\
\hline & Survivaly $^{y}$ & Flowering $^{\mathrm{x}}$ & Survival & Flowering \\
\hline & \multicolumn{4}{|c|}{$(\%)$} \\
\hline \multicolumn{5}{|l|}{ Cultivar ${ }^{\mathrm{z}}$} \\
\hline Walla Walla & $88 a^{w}$ & $6 \mathrm{c}$ & $63 \mathrm{a}$ & $3 c$ \\
\hline Olympic & $85 \mathrm{a}$ & $0 \mathrm{c}$ & $50 \mathrm{~b}$ & $1 \mathrm{c}$ \\
\hline Ailsa Craig & $68 \mathrm{~b}$ & $7 \mathrm{c}$ & $42 \mathrm{~b}$ & $3 c$ \\
\hline Candy & $61 \mathrm{~b}$ & $36 \mathrm{a}$ & $49 \mathrm{~b}$ & 33 a \\
\hline Superstar & $49 \mathrm{c}$ & $22 \mathrm{~b}$ & $40 \mathrm{~b}$ & 39 a \\
\hline Expression & $48 \mathrm{c}$ & $34 \mathrm{a}$ & $28 \mathrm{c}$ & $24 \mathrm{~b}$ \\
\hline WI-131 & $36 \mathrm{~d}$ & $0 \mathrm{c}$ & $20 \mathrm{c}$ & $0 \mathrm{c}$ \\
\hline \multicolumn{5}{|c|}{ Overwintering Protection ${ }^{\mathrm{v}}$} \\
\hline Rowcover & 88 a & $28 \mathrm{a}$ & $67 \mathrm{a}$ & $24 \mathrm{a}$ \\
\hline Wheat straw & $36 \mathrm{~b}$ & $2 \mathrm{~b}$ & $17 \mathrm{~b}$ & $5 \mathrm{~b}$ \\
\hline \multicolumn{5}{|l|}{ Year } \\
\hline 2007-08 & $62 \mathrm{a}$ & $15 \mathrm{a}$ & & \\
\hline $2008-09$ & $42 \mathrm{~b}$ & $14 \mathrm{a}$ & & \\
\hline
\end{tabular}

z'Ailsa Craig', 'Olympic', and 'Walla Walla' (long-day); 'Candy,' 'Expression,' and 'Superstar' (intermediate-day); 'WI-131' (short-day).

yercent survival based on the number of plants surviving out of 200 planted.

xPercentage of flowering were based on number of plants that had bolted divided by the number of plants surviving in each plot.

"Means within a column followed by the same letter are not significantly different according to Fisher's least significant difference test at $P \leq 0.05$.

${ }^{v}$ Overwintering protection treatments were rowcovers (AG 50 ${ }^{\circledR}$; Agribon, Mooresville, NC) and wheat-straw mulch applied at a depth of 3 inches $(7.6 \mathrm{~cm})$.

under rowcovers compared with straw mulch, with 12.7- and 7.1-fold increases in survival in 2007-08 and 2008-09, respectively. Thus, although rowcovers increased survival of those cultivars, many of the surviving plants bolted, rendering bulbs unmarketable. 'Expression' had an $89 \%$ survival rate when grown using rowcovers compared with just $7 \%$ when grown using straw mulch in 2007-08 (Table 1). However, 67\% of the 'Expression' plants under rowcovers bolted compared with $0 \%$ of those grown with straw mulch. The average rates of bolting in 2007-08 and 2008-09 for all cultivars grown with rowcovers were $28 \%$ and $24 \%$, respectively; whereas the rates of bolting for onions grown using wheatstraw mulch were significantly lower at $2 \%$ and $5 \%$ in $2007-08$ and 2008 09 , respectively (Table 2 ). Our data suggests that bolting was induced primarily in intermediate-day cultivars grown under rowcovers. Generally, these cultivars also had low survival rates when grown using wheat-straw mulch. Although biennial, onions can undergo vernalization after reaching a minimum growth stage during the first year (Rabinowitch, 1990). The intermediate-day onions that bolted likely experienced adequate chilling hours while grown under rowcovers, which induced flowering. The longand short-day onion cultivars evaluated in this study, Walla Walla, Olympic, Ailsa Craig, and WI-131 had a lower propensity to flower regardless of the protective treatment used.

There were no significant differences in bolting rates when production years were compared (Table 2). In a 2 -year study in New Hampshire, Sideman and Bryant (2013) reported an increase in bolting in onions planted on 20 Sept. compared with those planted on either 30 Sept. or 20 Oct. In the present study, onions were planted $\approx 2$ weeks earlier in 2008-09 compared with 2007-08, and there may have been an increased risk in bolting in the 2008-09 production season; however, increased bolting was not observed.

ONION PLANT YIELD. There were rowcover/mulch treatment by onion cultivar interactions $(P \leq 0.05)$ for total marketable-, colossal-, jumbo-, and medium-bulb yield, and percent culls (Table 3 ). Production year significantly affected all yield parameters, with marketable yields generally being greater in 2007-08 and culls being greater in 2008-09. When
'Olympic' was grown under rowcovers, it had the largest total yield in both years; but in 2007-08, it did not differ $(P \leq 0.05)$ from 'Ailsa Craig' and 'Walla Walla' grown under rowcovers and 'Walla Walla' grown with wheat-straw mulch. In 200809, the total marketable yield of 'Olympic' did not differ $(P \leq 0.05)$ from 'Ailsa Craig' when grown under rowcovers (Table 3 ). Total marketable yields of 50-lb bags in 2007-08 ranged from 2 bags/acre for 'WI131' grown with straw mulch to 700 bags/acre for 'Olympic' grown under rowcovers. In 2008-09, total marketable yields ranged from $1 \mathrm{bag} /$ acre for 'WI-131' grown with straw mulch to 441 bags/acre for 'Olympic' grown under rowcovers. In both production years, 'Walla Walla' yielded the greatest amount of colossalsized bulbs, whereas 'Olympic' and 'Ailsa Craig' grown under rowcovers had the greatest yields of jumbo-sized bulbs. For medium-sized bulbs, 'Olympic' grown under rowcovers had the greatest yields during both years of the experiment.

In general, total marketable yield represented survival and bolting rates, with the exception of 'Walla Walla' in 2008-09, which had high cull rates primarily because of the presence of onion neck rot (Botrytis aclada). Cull rates followed trends of onion cultivar bolting responses. 'Expression' and 'Candy' grown under rowcovers had $59 \%$ and $60 \%$, respectively, of harvested bulbs culled in 2007-08 and 'Superstar' had $79 \%$ of harvested bulbs culled in 2008-09 (Table 3). Nearly all of these culls were the result of bolting. Year also interacted with cultivar and rowcover/mulch treatment for total yield $(P \leq 0.05)$. In 2007-08, 'Walla Walla' and 'Candy' did not benefit from being grown under rowcovers, but in 2008-09, 'Walla Walla' had a total marketable yield which was nearly $50 \%$ greater when grown under rowcovers compared with straw mulch.

In 2007-08, 'Olympic' and 'Walla Walla' grown with mulch or rowcovers and 'Ailsa Craig' grown with rowcovers had total marketable yields of 50-lb bags ranging from 489 to 700 , bags/acre (Table 3 ), which are comparable to spring-planted onions in Kentucky (Coolong et al., 2008). In 2008-09, total marketable yields of the highest yielding cultivars, 
Olympic and Ailsa Craig, grown under rowcovers, were 441 and 430 bags/acre, respectively, which are generally lower than spring-planted onion in Kentucky.

OnION QUALITY. Cultivar and rowcover/mulch treatment did not interact $(P \leq 0.05)$ to affected multiple centers, pungency, or SSC. Onion cultivars differed for multiple centers, SSC, and pungency in both years, while rowcover/mulch treatment affected SSC and pungency only in 2007-08
(Table 4). The incidence of multiple centers was lower in 2007-08, whereas SSC and pungency were lower in 2008-09 than in 2007-08 (Table 4). Fresh market onion requirements generally dictate that $\approx 70 \%$ of bulbs should have single centers (Cramer, 2006; Pelter et al., 2004). 'Olympic' and 'WI-131' had the lowest rates of multiple centers in the study. 'Walla Walla' had the highest percentage of multiple centers in 2007-08 at $88 \%$ and was also one of the cultivars with the highest amount of multiple centers in 2008-09 (Table 4). More bulbs from 'Walla Walla' were graded in the colossal-size category than other cultivars, which may have contributed to the high number of multiple centers. Rowcover/mulch treatment had no effect on the incidence of multiple centers in either year.

Soluble solids were highest in 'Candy' in both study years with $9.4 \%$ and $7.4 \%$ in 2007-08 and 2008-09, respectively. Onion bulb

Table 3. Total marketable-, colossal-, jumbo-, and medium-bulb yield, and cull rate for seven onion cultivars grown through the winters of 2007-08 and 2008-09 with rowcovers [R (AG 50 ${ }^{\circledR}$; Agribon, Mooresville, NC)] or wheat-straw mulch (S) in Lexington, KY.

\begin{tabular}{|c|c|c|c|c|c|c|c|c|c|c|}
\hline \multirow[b]{2}{*}{ Cultivar (treatment) } & \multicolumn{5}{|c|}{ 2007-08 Yield (50-lb bags/acre) ${ }^{\mathrm{z}}$} & \multicolumn{5}{|c|}{ 2008-09 Yield (50-lb bags/acre) } \\
\hline & Total & Colossal & Jumbo & Medium & Cull (\%) & Total & Colossal & Jumbo & Medium & Cull (\%) \\
\hline Olympic (R) & $700 a^{x}$ & $46 \mathrm{~cd}$ & $421 \mathrm{a}$ & $233 a$ & $1 \mathrm{e}$ & $441 \mathrm{a}$ & $25 \mathrm{c}$ & $230 \mathrm{a}$ & $186 a$ & $14 \mathrm{de}$ \\
\hline Ailsa Craig ( $\mathrm{R})$ & $603 \mathrm{ab}$ & $107 \mathrm{c}$ & $363 \mathrm{a}$ & $133 \mathrm{bcd}$ & $13 \mathrm{cde}$ & $430 \mathrm{a}$ & $84 \mathrm{~b}$ & $213 \mathrm{a}$ & $133 \mathrm{~b}$ & $30 \mathrm{~cd}$ \\
\hline Walla Walla $(\mathrm{R})$ & $603 \mathrm{ab}$ & $203 \mathrm{~b}$ & $312 \mathrm{~b}$ & 88 ed & 13 cde & $314 \mathrm{~b}$ & $164 \mathrm{a}$ & $116 \mathrm{~b}$ & $34 \mathrm{c}-\mathrm{f}$ & $59 \mathrm{ab}$ \\
\hline Walla Walla $(S)$ & $592 \mathrm{ab}$ & $322 \mathrm{a}$ & $222 \mathrm{c}$ & $48 \mathrm{efg}$ & 8 de & $177 \mathrm{c}$ & $88 \mathrm{~b}$ & $62 \mathrm{~b}-\mathrm{e}$ & $27 \mathrm{c}-\mathrm{f}$ & $44 \mathrm{bc}$ \\
\hline Olympic $(S)$ & $489 \mathrm{~b}$ & $19 \mathrm{~d}$ & $299 \mathrm{~b}$ & $171 \mathrm{~b}$ & $0 \mathrm{e}$ & $131 \mathrm{cde}$ & $14 \mathrm{c}$ & $72 \mathrm{bcd}$ & 44 cde & $14 \mathrm{de}$ \\
\hline Candy $(S)$ & $157 \mathrm{de}$ & $7 \mathrm{~d}$ & $105 \mathrm{de}$ & $46 \mathrm{efg}$ & $24 \mathrm{bc}$ & $76 \mathrm{cde}$ & $5 \mathrm{c}$ & 54 b-e & $17 \mathrm{def}$ & $25 \mathrm{~cd}$ \\
\hline Candy (R) & $148 \mathrm{de}$ & $0 \mathrm{~d}$ & $55 \mathrm{ef}$ & $93 \mathrm{cde}$ & $60 \mathrm{a}$ & $159 \mathrm{~cd}$ & $16 \mathrm{c}$ & $82 \mathrm{bcd}$ & $61 \mathrm{c}$ & $63 \mathrm{ab}$ \\
\hline Expression (R) & $110 \mathrm{ef}$ & $0 \mathrm{~d}$ & $52 \mathrm{ef}$ & $58 \mathrm{efg}$ & 59 a & $161 \mathrm{~cd}$ & $10 \mathrm{c}$ & $100 \mathrm{bc}$ & $52 \mathrm{~cd}$ & $53 \mathrm{~b}$ \\
\hline WI-131 (R) & $89 \mathrm{ef}$ & $0 \mathrm{~d}$ & $9 \mathrm{f}$ & 80 efd & $16 \mathrm{cde}$ & $28 \mathrm{f}$ & $0 \mathrm{c}$ & $4 \mathrm{e}$ & $24 \mathrm{def}$ & $32 \mathrm{~cd}$ \\
\hline Superstar (S) & $46 \mathrm{ef}$ & $0 \mathrm{~d}$ & $22 \mathrm{f}$ & $24 \mathrm{fg}$ & $23 \mathrm{bcd}$ & $48 \mathrm{ef}$ & $4 \mathrm{c}$ & $32 \mathrm{de}$ & $12 \mathrm{ef}$ & $44 \mathrm{bc}$ \\
\hline Expression $(S)$ & $28 \mathrm{f}$ & $0 \mathrm{~d}$ & $22 \mathrm{f}$ & $6 \mathrm{~g}$ & 11 cde & $36 \mathrm{ef}$ & $4 \mathrm{c}$ & $26 \mathrm{de}$ & $6 \mathrm{f}$ & $30 \mathrm{~cd}$ \\
\hline
\end{tabular}

${ }^{2}$ Onion yields are based on populations of 72,000 plants $/$ acre $(177,915.9$ plants $/ \mathrm{ha})$, one $50-\mathrm{lb}(22.7 \mathrm{~kg}) \mathrm{bag} / \mathrm{acre}=56.0426 \mathrm{~kg} \cdot \mathrm{ha}{ }^{-1}$.

y Percentage culls were based on weight of culls (small and unmarketable bulbs) divided by total harvested weight.

${ }^{x}$ Means within a column followed by the same letter are not significantly different according to Fisher's least significant difference test at $P \leq 0.05$.

Table 4. Percentage multiple centers, soluble solids content (SSC), and enzymatically produced pyruvic acid content (EPY) of seven onion cultivars and overwintering protection treatments for plants grown through the winters of 2007-08 and $2008-$ 09 in Lexington, KY.

\begin{tabular}{|c|c|c|c|c|c|c|}
\hline & \multicolumn{3}{|c|}{ 2007-08 } & \multicolumn{3}{|c|}{ 2008-09 } \\
\hline & $\begin{array}{c}\text { Multiple } \\
\text { centers (\%) }\end{array}$ & SSC (\%) & $\begin{array}{c}\text { EPY } \\
\left(\mu \mathrm{mol} \cdot \mathrm{mL}^{-1} \text { juice }\right)^{\mathrm{z}}\end{array}$ & $\begin{array}{c}\text { Multiple } \\
\text { centers (\%) }\end{array}$ & SSC (\%) & $\begin{array}{c}\mathrm{EPY} \\
\left(\mu \mathrm{mol} \cdot \mathrm{mL}^{-1} \text { juice }\right) \\
\end{array}$ \\
\hline Ailsa Craig & $35 c^{y}$ & $7.8 \mathrm{c}$ & $5.0 \mathrm{c}$ & $57 \mathrm{a}$ & $5.9 \mathrm{c}$ & $3.6 \mathrm{bc}$ \\
\hline Candy & $57 \mathrm{~b}$ & $9.4 \mathrm{a}$ & $6.5 \mathrm{~b}$ & $49 \mathrm{a}$ & $7.4 \mathrm{a}$ & $4.4 \mathrm{a}$ \\
\hline Superstar & $40 \mathrm{c}$ & $9.0 \mathrm{~b}$ & $7.2 \mathrm{a}$ & $50 \mathrm{a}$ & $6.5 \mathrm{~b}$ & $4.0 \mathrm{abc}$ \\
\hline WI-131 & $0 \mathrm{~d}$ & $6.8 \mathrm{e}$ & $2.3 \mathrm{e}$ & $7 \mathrm{~b}$ & $5.5 \mathrm{c}$ & $4.1 \mathrm{ab}$ \\
\hline Olympic & $6 \mathrm{~d}$ & $9.2 \mathrm{ab}$ & $3.4 \mathrm{~d}$ & $3 \mathrm{~b}$ & $5.8 \mathrm{c}$ & $3.6 \mathrm{bc}$ \\
\hline \multicolumn{7}{|c|}{ Overwintering Protection ${ }^{\mathrm{w}}$} \\
\hline Rowcover & $35 \mathrm{a}$ & $8.2 \mathrm{~b}$ & $4.8 \mathrm{~b}$ & $52 \mathrm{a}$ & $6.2 \mathrm{a}$ & $4.0 \mathrm{a}$ \\
\hline Wheat straw & $30 \mathrm{a}$ & $8.6 \mathrm{a}$ & $5.8 \mathrm{a}$ & $41 \mathrm{a}$ & $6.1 \mathrm{a}$ & $3.6 \mathrm{a}$ \\
\hline
\end{tabular}

${ }^{2}$ Pungency is expressed as micromoles of pyruvate per milliliter of onion juice from crushed onions.

'Means within a column followed by the same letter are not significantly different according to Fisher's least significant difference test at $P \leq 0.05$.

"Expression" was not analyzed for EPY in 2008.

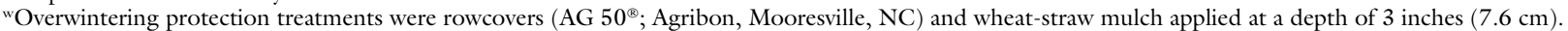


SSC was higher in 2007-08, ranging from $6.8 \%$ to $9.4 \%$ compared with 2008-09, where it ranged from $5.5 \%$ to $7.4 \%$. Onion cultivars grown under rowcovers had a lower SSC compared with those grown with wheat-straw mulch in 2007-08; although, SSC did not differ between the two treatments in 2008-09.

Onion bulb pungency was affected by cultivar in both years (Table 4). In 2007-08, 'WI-131' had the lowest pungency with $2.3 \mu \mathrm{mol}$ pyruvate per milliliter of juice and 'Superstar' was the highest at 7.2 $\mu \mathrm{mol} \cdot \mathrm{mL}^{-1}$ pyruvate. Furthermore, in 2008-09, 'Walla Walla' had the lowest pungency at $3.4 \mu \mathrm{mol} \cdot \mathrm{mL}^{-1}$ pyruvate, whereas 'Candy' had the highest pungency at $4.4 \mu \mathrm{mol} \cdot \mathrm{mL}^{-1}$ pyruvate; however, several other cultivars had pungency levels that were not significantly different from either 'Candy' or 'Walla Walla.' Production year also affected pungency, with an average of $5.1 \mu \mathrm{mol} \cdot \mathrm{mL}^{-1}$ pyruvate in 2007-08 and $3.8 \mu \mathrm{mol} \cdot \mathrm{mL}^{-1}$ pyruvate in 2008-09. In 2007-08, pungencies were lower in bulbs grown under rowcovers than with wheatstraw mulch, though there were no effects of rowcover in 2008-09. Onions sold as mild-sweet types typically have pungencies below $4 \mu \mathrm{mol} \cdot \mathrm{mL}^{-1}$ pyruvate (W.M. Randle, personal communication). This suggests that 'WI-131' and 'Olympic' would have low pungencies that would allow them to be marketed as a sweet onion in 2007-08, whereas nearly all cultivars evaluated could have been marketed as sweet onions in 2008-09. Environmental factors such as temperature, sulfur, and nitrogen fertility have been previously shown to directly impact pungency in onion (Coolong and Randle, 2003a,b). Sulfur and nitrogen fertility were supplied to plants at similar levels in both growing seasons and likely did not influence yearly differences in pungency. This suggests that the differences observed may have been the result of variables such as temperature or rainfall.

\section{Conclusions}

While intermediate-day onion cultivars are recommended for spring production in Kentucky and nearby states (Coolong et al., 2011; Kemble et al., 2013), our results suggest that long-day cultivars may be more suitable for overwinter production. The long-day onion cultivars evaluated had higher overwinter survival rates and lower rates of bolting. Rowcovers increased onion plant survival compared with straw mulch. However, for intermediate-day onions, the improved survival rates attributed to rowcovers were not beneficial because of the induction of bolting. Rowcovers did increase survival rates of long-day types, without a concomitant increase in bolting. Yields were directly related to improved survival rates and bolting incidence, with longday cultivars having greater yields than intermediate and short-day types. Average onion yields in 50 -lb bags for the United States are $\approx 840$ bags/acre (Maynard and Hochmuth, 2007). Although the yields in this study were lower than the national average, they may be sufficient for growers direct marketing their products. Our data suggests that the long-day onion cultivars evaluated were more suitable for overwinter production than the intermediate-day types that are commonly planted in this region of the United States. The long-day onion cultivar, Olympic, combined high yields with mild flavor potential and should be considered for overwinter production in Kentucky and nearby states.

\section{Literature cited}

Boyhan, G.E. and W.T. Kelley. 2007. Onion production guide. Univ. of Georgia Coop. Ext. Serv. Bul. B-1198-2.

Boyhan, G.E. and R.L. Torrance. 2002. Vidalia onions-Sweet onion production in southeastern Georgia. HortTechnology 12:196-202.

Brewster, J.L. 1990. Physiology of crop growth and bulbing, p. 53-88. In: H. Rabinowitch and J.L. Brewster (eds.). Onions and allied crops. Vol. I: Botany, physiology, and genetics. CRC Press, Boca Raton, FL.

Coolong, T.W. and W.M. Randle. 2003a. Temperature influences flavor intensity and quality in 'Granex 33' onion. J. Amer. Soc. Hort. Sci. 128:176-181.

Coolong, T.W. and W.M. Randle. 2003b. Sulfur and nitrogen availability interact to affect the flavor biosynthetic pathway in onion. J. Amer. Soc. Hort. Sci. 128:776783.

Coolong, T.W., J. Pfeiffer, and D. Slone. 2008. Spring onion cultivar evaluation in central Kentucky, p. 38-39. In: 2008
Fruit and vegetable research report. Univ. Kentucky Coop. Ext. Serv. Bul. PR-572.

Coolong, T., R. Bessin, K. Seebold, J. Strang, and S. Wright. 2011. Vegetable production guide for commercial growers 2012-13. Univ. Kentucky Coop. Ext. Serv. Bul. ID-36.

Corgan, J.N. and N. Kedar. 1990. Onion cultivation in subtropical climates, p. 3247. In: H. Rabinowitch and J.L. Brewster (eds.). Onions and allied crops. Vol. II: Agronomy, biotic interactions, pathology, and crop protection. CRC Press, Boca Raton, FL.

Cramer, C. 2006. Onion trait heritability and response from selection. J. Amer. Soc. Hort. Sci. 131:646-650.

Diaz-Perez, J.C., W.M. Randle, G. Boyhan, R.W. Walcott, D. Giddings, D. Bertrand, H.F. Sanders, and R.D. Gitaitis. 2004. Effects of mulch and irrigation system on sweet onion 1. Bolting, plant growth, and bulb yield and quality. J. Amer. Soc. Hort. Sci. 129:218-224.

Gill, P.A. and P.D. Waister. 1983. Winter hardiness in autumn-sown onions ( $\mathrm{Al}$ lium cepa L.). Crop Res. 23:17-31.

Hanelt, P. 1990. Taxonomy, evolution, and history, p. 1-26. In: H. Rabinowitch and J.L. Brewster (eds.). Onions and allied crops. Vol. I: Botany, physiology, and genetics. CRC Press, Boca Raton, FL.

Hochmuth, R.C., S.M. Olson, and G.J. Hochmuth. 1990. Short day onion cultivars for north Florida. Proc. Florida State Hort. Soc. 103:96-98.

Ibarra, L.J.F. and J.C. Diaz-Perez. 2001. Growth and yield of muskmelon in response to plastic mulch and rowcovers. Sci. Hort. 87:139-145.

Kemble, J.M., K. Ivors, F.J. Louws, K.M. Jennings and J.F. Walgenbach 2013. Southeastern U.S. vegetable crop handbook. Vance Publishing, Lincolnshire, IL.

Lamont, W.J. 2005. Plastics: Modifying the microclimate for the production of vegetable crops. HortTechnology 15:477-481.

Mansour, N.S. and D.D. Hemphill. 1987. Bunching onion response to floating rowcovers. HortScience 22:318-319.

Maynard, D. and G. Hochmuth. 2007. Knott's handbook for vegetable growers. 5 th ed. Wiley, Hoboken, NJ.

Pelter, G.Q., R. Mittelstadt, B.G. Leib, and C.A. Redulla. 2004. Effects of water stress at specific growth stages on onion bulb yield and quality. Agr. Water Mgt. 68:107-115.

Rabinowitch, H.D. 1990. Physiology of flowering, p. 113-134. In: H. Rabinowitch 


\section{Research Reports}

and J.L. Brewster (eds.). Onions and allied crops. Vol. I: Botany, physiology, and genetics. CRC Press, Boca Raton, FL.

Randle, W.M. and M.L. Bussard. 1993. Streamlining onion pungency analysis. HortScience 28:60.

Rubatzky, V.E. and M. Yamaguchi. 1997. World vegetables: Principles, production, and nutritive values. Chapman and Hall, New York, NY.
Schwartz, H.F. and S.K. Mohan. 1995. Compendium of onion and garlic diseases. APS Press, St. Paul, MN.

Sideman, B. and H. Bryant. 2013. Research report: Overwintering onions in low tunnels, 2012 and 2013. 8 June 2014 $<$ http://extension.unh.edu/resources/ representation/Resource003239_Rep4 688.pdf>.

Sobeih, W.Y. and C.J. Wright. 1986. The photoperiodic regulation of bulbing in onions (Allium cepa L.) II. Effects of plant age and size. J. Hort. Sci. 61:337-341.

University of Kentucky. 2014. Lexington, Kentucky climate data. 4 Feb. 2014. <http://wwwagwx.ca.uky.edu/cgi-bin/ ky_clim_data_www.pl>.

U.S. Department of Agriculture. 1995. United States standards for grades of Bermuda-Granex-Grano type onions. U.S. Dept. Agr., Washington, DC.

Walters, S.A. 2008. Production method and cultivar effects on garlic over-wintering survival, bulb quality, and yield. HortTechnology 18:286-289. 